\title{
軸対称不足膨張噴流における噴流境界とマッハディスクの特性
}

\section{Characteristics of Jet Boundary and Mach Disk of Under-Expanded Axisymmetric Air Jet}

\section{○ 正 乙部由美子（北九州高専） 正 松尾 繁（佐賀大）}

\section{正 樫村秀男（北九州高専） \\ 学 田中征将（佐賀大院） 正 瀬戸口俊明（佐賀大）}

\begin{abstract}
Yumiko OTOBE, Kitakyushu National College of Technology,5-20-1 Shii, Kokuraminami-ku, Kitakyushu 802-0985 Hideo KASHIMURA, Kitakyushu National College of Technology,5-20-1 Shii, Kokuraminami-ku, Kitakyushu 802-0985 Shigeru MATSUO, Saga University, 1, Honjo, Saga 840-8502 Masanori TANAKA, Saga University, 1, Honjo, Saga 840-8502 Toshiaki SETOGUCHI, Saga University, 1, Honjo, Saga 840-8502
\end{abstract}

Key Words: Compressible Flow, Supersonic Jet, Mach Disk, Nozzle Geometry, Jet Boundary

\section{1 まえがき}

超音速噴流の多くは，マッハディスク，バレル衝撃波, 反 射衝撃波などを含む不足膨張噴流であり, 本研究では音速ノ ズルから発生する超音速噴流中で，そのノズル形状の影響を

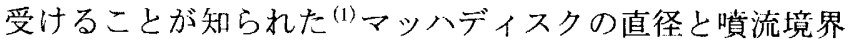
の傾きとの関係を数值計算により明らかにした.

\section{2 数値計算方法}

流れの中心軸方向を $\boldsymbol{x}$ ，半径方向を $r$ とする円筒座標系 $(x-r)$ に扔ける非粘性非定常圧縮性軸対称オイラーノ程式を 一般座標系 $(\xi-\eta)$ に変換し, 三次精度TVD有限差分スキーム (2)を用いて計算を行なった。供試モデルとしてConverging） ズル (N1), Sharp-Edgedノズル (N2), Sharp-Edgedオリフィ ス（N3）の 3 種類を用いた.

なお，気体の比熱比 $\kappa$ は 1.4 とし，貯気压 $p_{0}$ と背厈 $p_{\mathrm{b}}$ の比 を示す圧力比 $\phi$ は $5.5,7,8,9,10,12$ の場合を計算した。

\section{3 結果および考察}

ノズル出口近傍の噴流の形状は縮流の有無などノズル形 状により大きな違いがある。その状態を詳しく調べるため, Fig. 1 の (b) に示すように速度べクトルの角度 $\theta$ $\left(=\tan ^{-1} V / u\right)$ の半径方向における変化をグラフ化した. 図中の （b）は（a）に示す噴流の断面位置 $x=x_{1}$ における半径方向の 圧力 $p$, 速度 $U$ Ox成分 $u$, および速度 $U$ お傾き $\theta$ の変化を
示している. $\theta$ が最大值 $\theta_{\mathrm{A}}$ となるA'の半径方向変位は $r_{\mathrm{A}}$ で, その噴流中の位置はAとした．また同様に $\theta$ が值 $\theta_{\mathrm{B}}$ となる

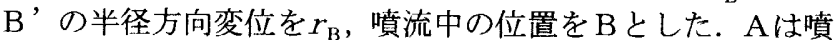
流境界に一致し，Bはバレル衝撃波に一致した。噴流境界の 傾きである $\theta_{B}$ から最大值 $\theta_{\mathrm{B}, \max }$ を求めマッハディスクの直 径 $D_{\mathrm{m}}$ との関倸を求めた。

\section{4 結論}

本研究により得られた結果は次のとおりである。

(1) 速度ベクトルの角度の半径方向における最大点 A はバレ ル衝撃波に一致し，偏極点Bは噴流境界に一致する。

(2) 速度べクトルの角度 $\theta_{\mathrm{B}}$ は噴流境界の傾斜と一致し，軸方 向における最大角度 $\theta_{\mathrm{B}, \text { max }}$ が存在する.

(3) 最大角度 $\theta_{\mathrm{B}, \text { max }}$ とマッハディスクの直径D鬲関係は, ノズ ルの形状に依存しない。

(4) ノズルモデル N1, N2, N3 に関して, 圧力比 5. 5, 7, 8, 9, 10, 12 においては, 最大角度 $\theta_{\mathrm{B}, \max }$ とマッハディスクの直待 $D_{\mathrm{m}} / D_{\mathrm{c}}$ の)関係を表す回㷌方程式は

$D_{\mathrm{m}} / D_{\mathrm{e}}=0.06359 \theta_{\mathrm{B}, \max }-0.5435$ で，相関係数は 0.9732 であ る.

\section{参考文献}

(1) Addy, A. L. , AIAA J. , Vol. 19, No. 1 (1981), pp. 121-122.

(2) Yee, H. C. , NASA TM-89464, 1989.

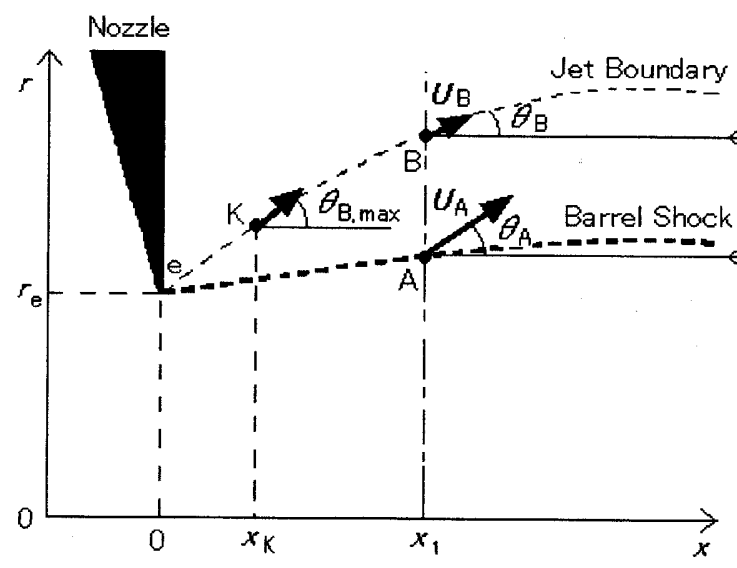

(a)

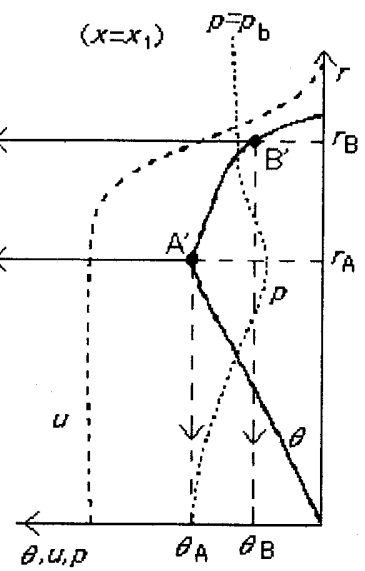

(b)

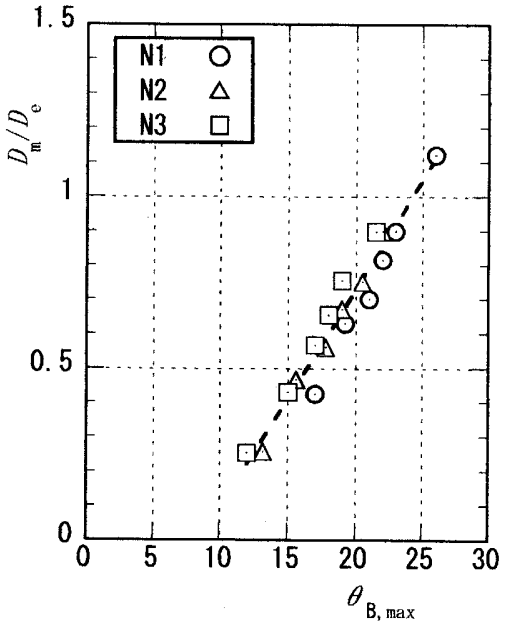

Fig.1 Schematic explanation of slopes of velocity vector $\theta_{\mathrm{A}}$ and $\theta_{\mathrm{B}}$

Fig.2 Relationships between $\theta_{\mathrm{B}, \max }$ and $D_{\mathrm{m}}$ 